\title{
EFFECT OF INORGANIC ACID SOLUTIONS ON ELECTROCHEMICAL BEHAVIOR OF TIN ELECTRODE
}

R. M. ABOU SHAHBA, A.S.I. AHMED, E.M. ATTIA AND A.E. ELSHENNAWY

Chemistry Department, Faculty of science (for girls), AL-Azhar University, Nasr City, Cairo, Egypt

\begin{abstract}
The electrochemical behavior of tin metal was studied in some inorganic acid solutions; $\mathrm{HCl}, \mathrm{HNO}_{3}, \mathrm{H}_{2} \mathrm{SO}_{4}$ and $\mathrm{H}_{3} \mathrm{PO}_{4}$, using the open circuit potential measurements and the potentiodynamic polarization technique. In addition, the metallographic structure of tin electrode was examined before and after immersion in test solution by using scanning electron microscope (SEM). The identification of the elements presented in the surface of specimen after immersion in different solutions was performed using an energy dispersion X-ray analysis (EDAX). The obtained results demonstrated that the aqueous dilution of $\mathrm{HCl}, \mathrm{H}_{2} \mathrm{SO}_{4}$ and $\mathrm{H}_{3} \mathrm{PO}_{4}$ retarded the corrosion of tin electrode, (hydroxyl ion plays a part in basic salt formation), while dilution of $\mathrm{HNO}_{3}$ acid accelerated the corrosion. It is evident from SEM image that, there were grain boundaries and the surface was more active and rougher in case of mechanically polished electrode. In non-polished electrode, the surface was covered with a protective layer; generally $\mathrm{SnO}_{2}$. In potentiodynamic polarization study, the formation of basic salt $\mathrm{Sn}(\mathrm{OH}) \mathrm{Cl}$ was preference to any other oxide in $\mathrm{HCl}$ solutions. The increase in $\mathrm{NO}_{2}$ concentration was responsible for the increase in the rate of dissolution in $\mathrm{HNO}_{3}$. The tin dissolution in sulphuric acid occurred through an intermediate of $\left(\mathrm{SnHSO}_{4} \mathrm{OH}\right)$ species.
\end{abstract}

\section{Introduction}

The study of tin is important because tin represents the most widely used metallic material, primarily due to the fact that it can be manufactured relatively cheaply. The main use of tin is in the canning industry, solders, bronze and dental amalgam. It is now possible to characterize at the nanoscale the chemical composition, structure and electronic properties of oxide films that grow on the surface of metals, while keeping them in solution and under potentiostatic control ${ }^{(1)}$. The kinetics of electrode processes on chemically pure and technical tin in solutions of sulfuric and hydrochloric acids at various temperatures were investigated ${ }^{(2)}$. In both acids, anodic polarization resulted in a film on the $\mathrm{Sn}$ electrode. It was darkbrown in $\mathrm{H}_{2} \mathrm{SO}_{4}$ (apparently $\mathrm{SnO}_{2}$ ) and grayish in $\mathrm{HCl}^{(3)}$. The rate of corrosion of tin in $\mathrm{H}_{2} \mathrm{SO}_{4}$ decreased slightly when the acid concentration rose from $0 \%$ to approximately $80 \%$. Above $80 \%$ acid concentration, the reaction was very vigorous $^{(4)}$. Under the conditions of anodic behavior and passivation of tin in solutions containing $\mathrm{H}_{3} \mathrm{PO}_{4}$ acid, normally a $\mathrm{SnO}_{2}$ film covered the Sn electrode ${ }^{(5)}$. Effects on passivation when the solution additionally contains nitric acid or potassium nitrate have also been studied ${ }^{(6)}$. 
The rate of corrosion in nitric acid attained its maximum value at about $4 \mathrm{M}$. The slow rate at high acid concentration was attributed to the formation of the stable oxide film ${ }^{(7)}$. The rate of corrosion was apparently controlled by the rate of decomposition of the nitrate ions or the diffusion of $\mathrm{HNO}_{3}$ acid ${ }^{(8)}$. Iodides of $\mathrm{Na}$ and $\mathrm{K}$ retarded the reaction between $\mathrm{HNO}_{3}$ and $\mathrm{Sn}$. This retardation might be due to the specific action of the alkali ions ${ }^{(9)}$. The influence of some organic acids was also studied. In citric and maleic acids the polarization curves exhibit an active /passive transition ${ }^{(10-13)}$. The pitting sensitivity of tin in a synthetic medium similar to industrial water was not affected by $\mathrm{pH}$ variation ${ }^{(14)}$. Addition of oxo-anions to the synthetic medium leads to retard a breakdown of passivation and the inhibition of pitting process of tin ${ }^{(15)}$.

The knowledge of the anodic behavior of tin is therefore of great interest. The present work was mainly concerned with the study of the behavior of tin electrode in different acids solutions.

\section{Experiment}

\section{Materials:}

The material used in the present study was spectroscopically pure tin rod electrode (99.999\% pure) with an apparent exposed area of $2 \mathrm{~cm}^{2}$. Tin rod was fixed to glass tubing with araldite adhesive. The electrical contact was made through a thick copper wire soldered to the inner side of the electrode. Prior to each experiment, the surface of the working electrode was prepared by polishing with different grades emery papers, then diamond paste $(1 \mu \mathrm{m})$, washing by distilled water, drying and quickly inserting it in the cell. For non polished electrode, it was prepared by the same way but after polishing, washing and drying it was left in air for 48 hour then it was inserted in the cell. The counter electrode was a platinum sheet.

\section{Adopted techniques:}

\section{I- Open-circuit potential measurements:}

The potential of tin electrode was measured in different concentrations of test solutions ranging from $\left(1 \times 10^{-5}\right.$ to $\left.2 \mathrm{M}\right)$. All measurements were carried out in conventional glass cell at room temperature. The potential was recorded as a function of time till steady state values were observed by using electronic multimeter (Type E scord- EDM-2116). The potentials were recorded relative to a saturated calomel electrode (SCE). 


\section{II- Potentiodynamic polarization measurements:}

Anodic and cathodic potentiodynamic polarization scans were performed with electronic potentioscane (Volt Lab PGZ 301 Dynamic EIS Voltammetry). The polarization cell used was multinecked $(100 \mathrm{ml})$ flask. The multiple necks were used to introduce working, auxiliary, reference electrodes and Luggin capillary. All measurements were performed in freshly prepared aerated solutions at room temperature $\left(25 \pm 2^{\circ} \mathrm{C}\right)$. The anodic E/I curves for all solutions were swept from 1500 to $1500 \mathrm{mV}$ at scan rate $20 \mathrm{mV} / \mathrm{s}$.

\section{Results And Discussion}

\section{I-Open-circuit potential measurements:}

(i) Behavior of mechanically polished electrode:

The behavior of tin electrode in different acidic solutions $\left(\mathrm{HCl}, \mathrm{HNO}_{3}, \mathrm{H}_{2} \mathrm{SO}_{4}\right.$ and $\mathrm{H}_{3} \mathrm{PO}_{4}$ ) was studied.

In low concentrations of $\mathrm{HCl}\left(10^{-5}\right.$ to $\left.10^{-3} \mathrm{M}\right)$, the potential was shifted with time towards more positive values. This was in accordance with Evans ${ }^{(16)}$ where the oxide film was self- healing. In low concentrations, the passivity increased with decreasing concentration, and the potential- time curves are characterized by a rapid rise in potential followed by steady state potential values $\left(E_{S S}\right)$. The initial rise in potential was believed to be connected with the anodic removal of adsorbed surface hydrogen as well as with the charging up of the electrical double layer at the metal/ solution interface. The steady state portion might be attributed to the formation of stannic oxide $\mathrm{SnO}_{2}$ on the electrode surface; this increases the resistance of anodic area which led to passivation. However, at higher concentrations of acid solution $\left(10^{-2}\right.$ to $\left.2 \mathrm{M}\right)$, the potential drifted with time towards more negative values denoting the destruction of the pre-immersion oxide film formed on the surface of the electrode (Figure 1). The same behavior was observed for $\mathrm{H}_{2} \mathrm{SO}_{4}$ and $\mathrm{H}_{3} \mathrm{PO}_{4}$ solutions.

In $\mathrm{HNO}_{3}$ acid solution, curves revealed that the steady state potentials approached from more negative values to the positive direction in all concentrations. The extent of the potential rise depends, primarily on solution concentration, being greater with increasing the acid concentration.

Within the whole test solutions and concentrations, the immersion potential values, $\mathrm{E}_{\mathrm{im}}$, lay negative side of the hydrogen/ hydrogen ion electrode system. This may indicate that the nature of the cathodic reaction occurring at the electrode surface is mainly hydrogen ion discharge (Equation 1) and the depolarization effect of oxygen was less manifested. 


$$
2 \mathrm{H}^{+}+2 \mathrm{e}^{-} \longrightarrow \mathrm{H}_{2}
$$

Figure (2) demonstrated the variation of the steady state potentials with the logarithm of the molar concentration of test solutions. Invariably straight lines are obtained according to the equation:

$$
\mathrm{E}_{\mathrm{SS}}=\mathrm{a}-\mathrm{b} \log \mathrm{C}
$$

where; (a) and (b) are constants depending on the type of test solutions. In equation 2, (a) represented the potentials of $1 \mathrm{M}$ concentration, being -418, -231, -370, and $-429 \mathrm{mV}$ for $\mathrm{HCl}, \mathrm{HNO}_{3}, \mathrm{H}_{2} \mathrm{SO}_{4}$ and $\mathrm{H}_{3} \mathrm{PO}_{4}$ respectively.

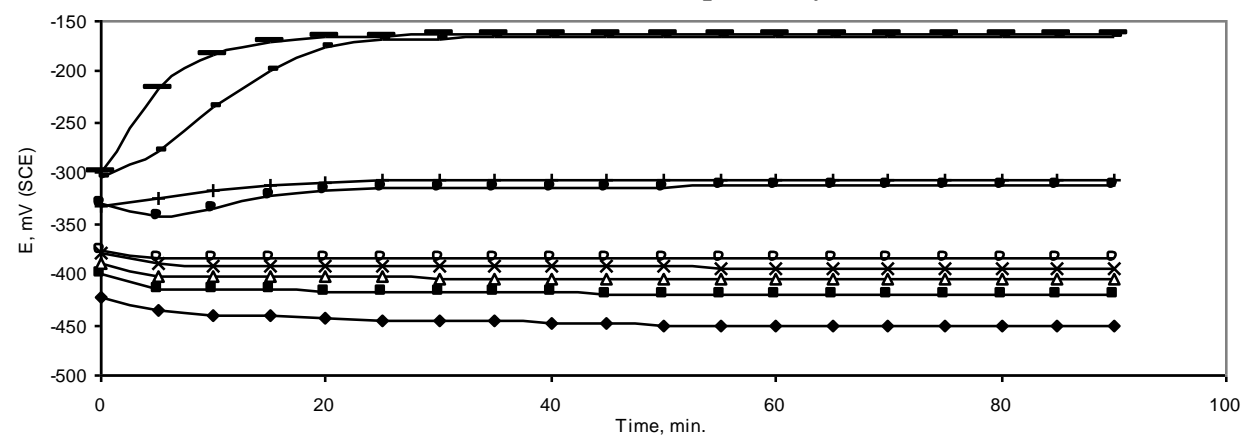

Figure (1): Potential- time curves of tin electrode in $\mathrm{HCl}$ solutions of

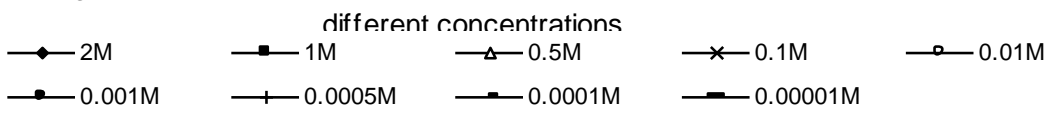

According to the change of the steady state potentials with the logarithmic concentration, the studied acids may be classified into two behaviors. The first one comprised $\left(\mathrm{HCl}, \mathrm{H}_{2} \mathrm{SO}_{4}\right.$ and $\left.\mathrm{H}_{3} \mathrm{PO}_{4}\right)$ which retarded the corrosion of tin electrode as the concentration of the acids decreased.

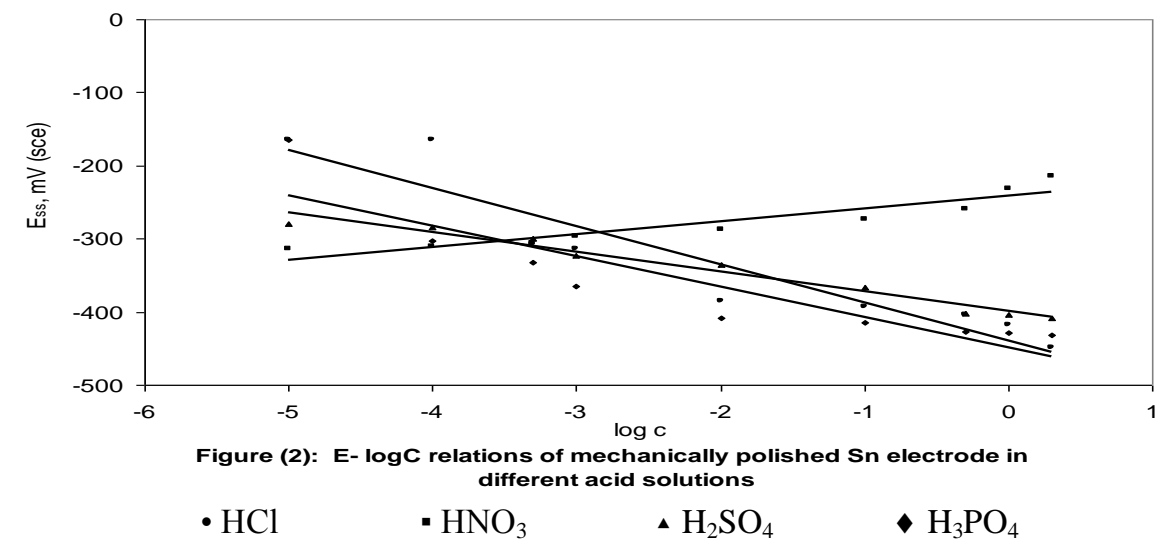


The second behavior belong $\left(\mathrm{HNO}_{3}\right)$ acid which accelerate the corrosion as the concentration decreased.

The more negative values of steady state potential, the more aggressive is the corresponding acid. Subsequently the corrosivety of these acids is assumed to increase in the following order: $\mathrm{HNO}_{3}<\mathrm{H}_{2} \mathrm{SO}_{4}<\mathrm{HCl}<\mathrm{H}_{3} \mathrm{PO}_{4}$

\section{(ii) Behavior of non polished electrode}

The general features of the potential- time curves for non polished electrode were materially the same as those for mechanically polished electrode but with higher potential values. This behavior was obtained for all acids studied. This may be facilitated by the presence of inner oxide film $\left(\mathrm{SnO}_{2}\right)$ due to exposure to air for a long period of time (48 hour) compared with that polished by mechanical way. Also, a linear relation held between the steady state potential and the logarithm of acid concentration (Figure 3). The order of corrosivety was similar to that of mechanically polished electrode.

The immersion potential and steady state potential values for tin electrode in all acidic solutions by using two methods are tabulated in Table (1).

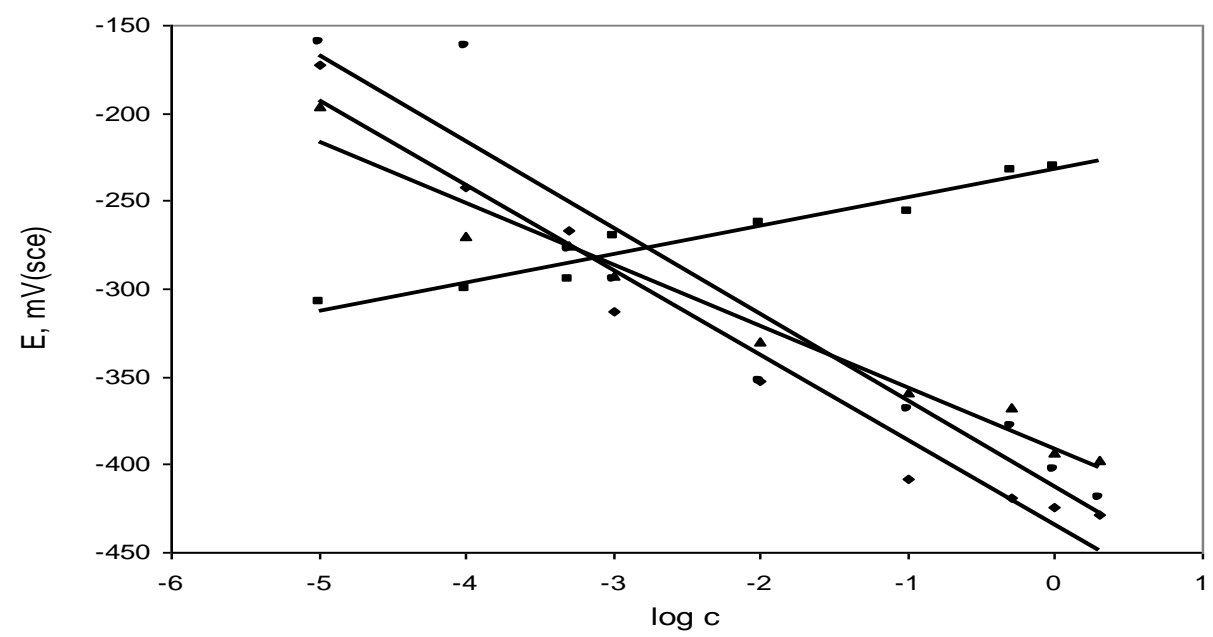

Figure (3): $\mathbf{E}-\log \mathrm{C}$ relations of non polished $\mathrm{Sn}$ electrode in different acids solutions
$\cdot \mathrm{HCl}$
- $\mathrm{HNO}_{3}$
$\triangle \mathrm{H}_{2} \mathrm{SO}_{4}$
- $\mathrm{H}_{3} \mathrm{PO}_{4}$ 


\section{(iii) Oxide film thickening}

The potential of the tin electrode varied linearly with the logarithm of the immersion time until a steady state potential was attained. The straight lines obtained satisfying the relation ${ }^{(17):}$

$$
\mathrm{E}=\text { Constant }+2.303 \delta^{-} / \beta \log \mathrm{t}
$$

where; $\mathrm{t}$, is the time from the moment of immersion in solution, $\delta^{-}$, is the rate of oxide film thickening per unit decade of time, and $\beta$ was given by:-

Table (1): Values of $E_{i m}$ and $E_{S S}$ in $\mathrm{mV}(\mathrm{SCE})$ for tin electrode in different acids solutions.

\begin{tabular}{|c|c|c|c|c|c|c|c|c|c|}
\hline \multirow{2}{*}{$\begin{array}{l}\text { Surface } \\
\text { treatment }\end{array}$} & \multirow{2}{*}{$\begin{array}{c}\text { Conc. } \\
\mathrm{M}\end{array}$} & \multicolumn{2}{|c|}{$\mathrm{HCl}$} & \multicolumn{2}{|c|}{$\mathrm{HNO}_{3}$} & \multicolumn{2}{|c|}{$\mathrm{H}_{2} \mathrm{SO}_{4}$} & \multicolumn{2}{|c|}{$\mathrm{H}_{3} \mathrm{PO}_{4}$} \\
\hline & & $\mathrm{E}_{\mathrm{im}}$ & $\mathrm{E}_{\mathrm{SS}}$ & $\mathrm{E}_{\mathrm{im}}$ & $\mathrm{E}_{\mathrm{SS}}$ & $\mathrm{E}_{\mathrm{im}}$ & $\mathrm{E}_{\mathrm{SS}}$ & $\mathrm{E}_{\mathrm{im}}$ & $\mathrm{E}_{\mathrm{SS}}$ \\
\hline \multirow{9}{*}{ 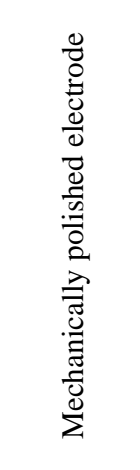 } & 2.0 & -423 & -448 & -225 & -215 & -405 & -408 & -428 & -431 \\
\hline & 1.0 & -400 & -418 & -247 & -231 & -400 & -403 & -422 & -429 \\
\hline & $5 \times 10^{-1}$ & -390 & -404 & -274 & -260 & -394 & -402 & -420 & -427 \\
\hline & $1 \times 10^{-1}$ & -380 & -393 & -286 & -274 & -345 & -366 & -407 & -414 \\
\hline & $1 \times 10^{-2}$ & -377 & -385 & -290 & -287 & -315 & -335 & -405 & -409 \\
\hline & $1 \times 10^{-3}$ & -330 & -314 & -310 & -296 & -298 & -323 & -398 & -365 \\
\hline & $5 \times 10^{-4}$ & -333 & -307 & -327 & -306 & -355 & -299 & -397 & -333 \\
\hline & $1 \times 10^{-4}$ & -304 & -165 & -332 & -310 & -332 & -284 & -395 & -303 \\
\hline & $1 \times 10^{-5}$ & -300 & -164 & -336 & -314 & -322 & -280 & -302 & -164 \\
\hline \multirow{9}{*}{ 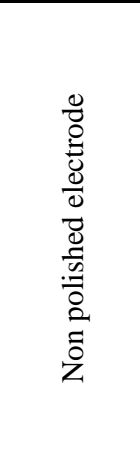 } & 2.0 & -401 & -419 & -200 & -105 & -388 & -398 & -405 & -429 \\
\hline & 1.0 & -388 & -403 & -235 & -230 & -372 & -393 & -410 & -424 \\
\hline & $5 \times 10^{-1}$ & -360 & -378 & -248 & -232 & -352 & -368 & -408 & -419 \\
\hline & $1 \times 10^{-1}$ & -335 & -369 & -269 & -256 & -339 & -359 & -393 & -408 \\
\hline & $1 \times 10^{-2}$ & -316 & -352 & -275 & -263 & -300 & -330 & -312 & -352 \\
\hline & $1 \times 10^{-3}$ & -301 & -295 & -290 & -270 & -315 & -292 & -332 & -313 \\
\hline & $5 \times 10^{-4}$ & -310 & -277 & -308 & -295 & -290 & -275 & -291 & -267 \\
\hline & $1 \times 10^{-4}$ & -298 & -162 & -313 & -300 & -276 & -270 & -280 & -242 \\
\hline & $1 \times 10^{-5}$ & -295 & -160 & -334 & -308 & -232 & -196 & -220 & -172 \\
\hline
\end{tabular}

$$
\beta=\mathrm{nF} / \mathrm{RT} \alpha \delta^{\prime}
$$

Where $\alpha$ was a transference coefficient similar to that encountered in normal electrochemical reactions where $(0<\alpha<1)$, and $\delta^{\prime}$ was the width of the energy 
barrier surrounded by the ion during transfer. Assuming $\alpha$ had the value of 0.5 and $\delta^{\prime}$ equal $1.0 \mathrm{~nm}$, "n" was set equal to 2 , then $\beta$ acquired the value of $39 \mathrm{~nm} / \mathrm{V}$. From the slopes of the $\mathrm{E}-\log \mathrm{t}$ relations, the values of $\delta^{-}$, have been calculated.

The value of the rate of film thickening in case of mechanically polished electrode was increased by decreasing acid concentration in case of $\mathrm{HCl}, \mathrm{H}_{2} \mathrm{SO}_{4}$ and $\mathrm{H}_{3} \mathrm{PO}_{4}$ while in $\mathrm{HNO}_{3}$ the rate was increased by increasing the concentration (Table 2). For non- polished electrode, the rate values are not affected regularly by concentration for all acids examined. It is clear that the rate was very high compared with mechanically polished electrode. This may be attributed to the presence of inner oxide film $\left(\mathrm{SnO}_{2}\right)$ resulted from long exposure to air.

Table (2): Slopes $b$ in $(\mathrm{mV} / \log t)$ of the $E$ vs. $\log t$ relations, and the rates of oxide film thickening $\delta^{-}$in $(\mathrm{nm} / \log \mathrm{t})$ of tin electrode in different acidic solutions

\begin{tabular}{|c|c|c|c|c|c|c|c|c|c|}
\hline \multirow{2}{*}{$\begin{array}{l}\text { Surface } \\
\text { treatment }\end{array}$} & \multirow{2}{*}{$\begin{array}{c}\text { Conc. } \\
\mathrm{M}\end{array}$} & \multicolumn{2}{|c|}{$\mathrm{HCl}$} & \multicolumn{2}{|c|}{$\mathrm{HNO}_{3}$} & \multicolumn{2}{|c|}{$\mathrm{H}_{2} \mathrm{SO}_{4}$} & \multicolumn{2}{|c|}{$\mathrm{H}_{3} \mathrm{PO}_{4}$} \\
\hline & & $\mathrm{b}$ & $\overline{\delta^{-}}$ & $\mathrm{b}$ & $\delta^{-}$ & $\mathrm{b}$ & $\delta^{-}$ & $\mathrm{b}$ & $\delta^{-}$ \\
\hline \multirow{9}{*}{ 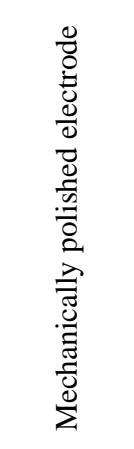 } & 2.0 & 7.20 & 0.12 & 14.10 & 0.23 & 4.30 & 0.07 & 1.44 & 0.02 \\
\hline & 1.0 & 6.60 & 0.11 & 12.80 & 0.21 & 4.30 & 0.07 & 3.30 & 0.05 \\
\hline & $5 \times 10^{-1}$ & 9.60 & 0.16 & 6.410 & 0.10 & 11.5 & 0.19 & 3.30 & 0.05 \\
\hline & $1 \times 10^{-1}$ & 11.1 & 0.18 & 5.120 & 0.08 & 14.2 & 0.24 & 4.30 & 0.07 \\
\hline & $1 \times 10^{-2}$ & 11.1 & 0.18 & 3.840 & 0.06 & 14.4 & 0.24 & 5.70 & 0.09 \\
\hline & $1 \times 10^{-3}$ & 10.0 & 0.16 & 2.560 & 0.04 & 30.4 & 0.51 & 28.2 & 0.47 \\
\hline & $5 \times 10^{-4}$ & 16.2 & 0.27 & 1.280 & 0.02 & 35.8 & 0.60 & 51.7 & 0.87 \\
\hline & $1 \times 10^{-4}$ & 70.6 & 1.19 & 1.280 & 0.02 & 38.4 & 0.64 & 83.5 & 1.41 \\
\hline & $1 \times 10^{-5}$ & 85.0 & 1.43 & 1.280 & 0.02 & 42.3 & 0.71 & 89.6 & 1.51 \\
\hline \multirow{9}{*}{ 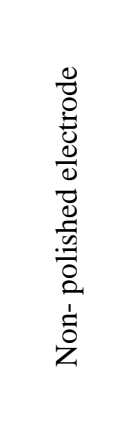 } & 2.0 & 15.72 & 266.3 & 0.44 & 7.46 & 6.96 & 117.8 & 5.39 & 91.41 \\
\hline & 1.0 & 3.63 & 61.55 & 0.88 & 14.92 & 7.01 & 118.7 & 5.04 & 85.48 \\
\hline & $5 \times 10^{-1}$ & 6.55 & 110.9 & 2.64 & 44.77 & 5.24 & 88.85 & 0.88 & 14.92 \\
\hline & $1 \times 10^{-1}$ & 9.87 & 167.2 & 0.88 & 14.92 & 2.64 & 44.75 & 4.51 & 76.49 \\
\hline & $1 \times 10^{-2}$ & 23.12 & 391.5 & 2.18 & 36.96 & 12.36 & 209.4 & 50.33 & 852.3 \\
\hline & $1 \times 10^{-3}$ & 3.63 & 61.55 & 18.17 & 307.8 & 4.82 & 81.72 & 21.55 & 365.1 \\
\hline & $5 \times 10^{-4}$ & 17.00 & 287.9 & 11.36 & 192.5 & 4.40 & 74.61 & 1.30 & 22.03 \\
\hline & $1 \times 10^{-4}$ & 119.9 & 2032 & 12.93 & 218.9 & 6.58 & 111.5 & 21.17 & 358.5 \\
\hline & $1 \times 10^{-5}$ & 54.15 & 916.9 & 14.27 & 241.7 & 6.58 & 111.5 & 21.84 & 396.9 \\
\hline
\end{tabular}




\section{II-Spectroscopic analysis}

The morphological changes of tin electrode surface were studied using scanning electron microscope (SEM) and energy dispersive X- ray analysis (EDAX). Figure (4) illustrated the morphology of tin electrode surface before exposure to corrosion media (Blank). The specimens were subjected to microscopic examination at $\mathrm{x} 1000$.

The photo-micrographs obtained for the specimen in $(1 \mathrm{M})$ nitric acid with polishing and non-polishing surface treatment are illustrated in Figures (5 and 6). In the two cases, the surface was subjected to three different microscopic examinations at $\times 500, x 1000$ and $x$ 1500. It is evident from SEM image that, there were grain boundaries and the surface was more active and rougher in case of mechanically polished electrode. While in non-polished electrode the surface is covered with a protective layer, generally $\mathrm{SnO}_{2}$.

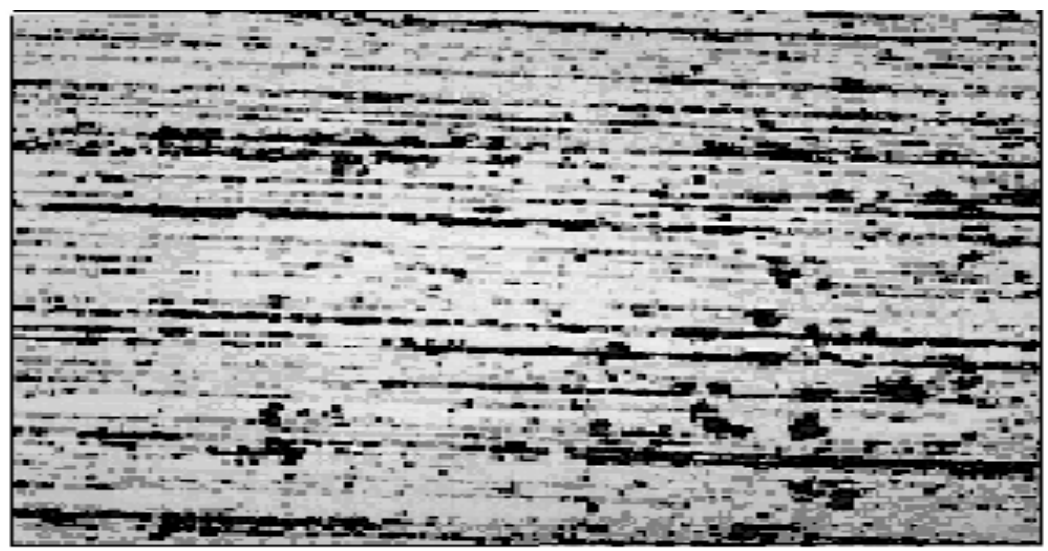

Figure (4): SEM micrograph of tin electrode (Blank) (X 1000)

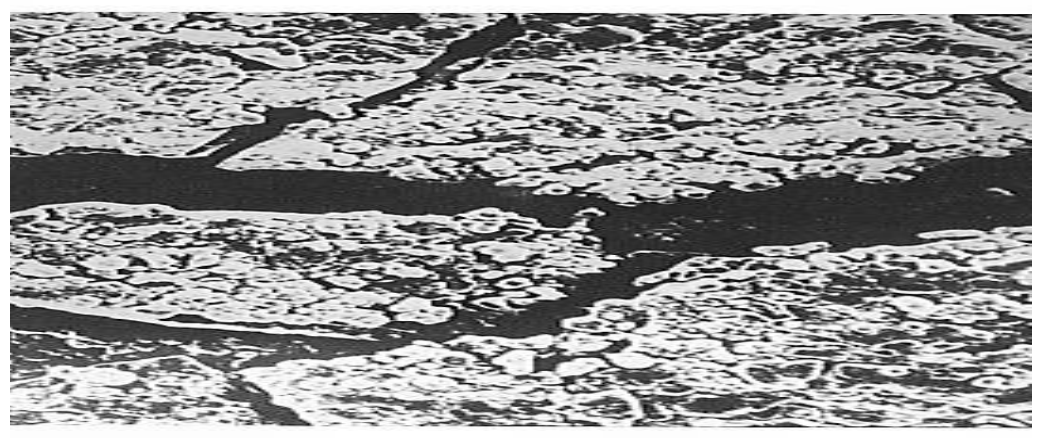

Figure (5): SEM micrograph of polished tin electrode in $1 \mathrm{M} \mathrm{HNO}_{3}(\mathrm{X} 1000)$ 
The EDAX spectra of tin electrode in $(1 \mathrm{M})$ of different acids solutions showed that the elements presented on the surface of tin electrode are $\mathrm{Sn}, \mathrm{O}_{2}, \mathrm{~S}, \mathrm{P}$ and $\mathrm{Cl}$ (Table 3). The higher percentage of oxygen in case of nitric acid may be due to the adsorption of $\mathrm{NO}_{2}$ on the tin surface. While, in other media the electrode surface is covered with unstable complex compound.

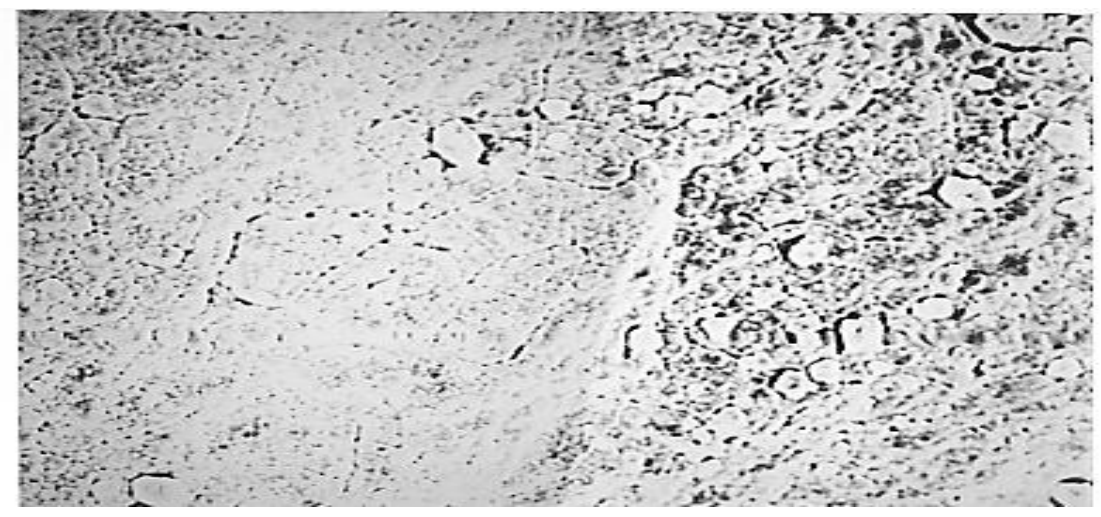

Figure (6): SEM micrograph of non- polished tin electrode in $1 \mathrm{M} \mathrm{HNO}_{3} \quad(\mathrm{X}$ 1000)

Table (3): The percentage of the elements presented on the surface of tin electrode in different acids solutions

\begin{tabular}{|c|c|c|c|c|c|}
\hline Medium & $\mathrm{Sn} \%$ & $\mathrm{O}_{2} \%$ & $\mathrm{~S} \%$ & $\mathrm{P} \%$ & $\mathrm{Cl} \%$ \\
\hline $\mathrm{HCl}$ & 87.73 & 10.73 & - & - & 1.54 \\
\hline $\mathrm{HNO}_{3}$ & 58.98 & 40.73 & - & - & - \\
\hline $\mathrm{H}_{2} \mathrm{SO}_{4}$ & 83.52 & 16.33 & 0.15 & - & - \\
\hline $\mathrm{H}_{3} \mathrm{PO}_{4}$ & 62.79 & 30.09 & - & 7.18 & - \\
\hline
\end{tabular}

\section{III- Potentiodynamic polarization measurements}

(a)- Behavior of tin electrode in hydrochloric acid

Figure (7) showed potentiodynamic polarization curves of tin electrode in various concentrations of $\mathrm{HCl}$ in the potential ranging from -1500 to $1500 \mathrm{mV}$ vs. $\mathrm{SCE}$ at scan rate of $20 \mathrm{mV} / \mathrm{s}$.

The passivation produced by hydrochloric acid solution is probably due to formation of a basic salt, $\mathrm{Sn}(\mathrm{OH}) \mathrm{Cl}^{(18)}$. The concentration of the acid played a part; when the dilution increased, there is a rapid rise in the critical potential (above 
which the regular dissolution of the metal ceases and the current density falls abruptly) ${ }^{(18)}$, which can be attributed, in case of the halogen acid to that, the tendency for insoluble basic salt to be formed diminishes as the dilution increases. The two beaks of $\left(10^{-2}-10^{-5}\right) \mathrm{M}$ with maximum reflected points that appeared at $\mathrm{E} \approx 0.35 \mathrm{~V}$ correspond to passive potential domain $\mathrm{E}_{\mathrm{p}}$ considering $\mathrm{Sn}(\mathrm{OH})_{2} \&$ $\mathrm{Sn}(\mathrm{OH})_{4}$ formation ${ }^{(19)}$, in presence of $\mathrm{Cl}^{-}$the basic chloride salt is preference. The passivation phenomenon is accompanied by a darkening of the electrode. This is caused either through an irregular attack by the solution giving rise to finely divided metal, or through the appearance of impurities in the tin electrode.

By establishing a potential- $\mathrm{pH}$ diagram representing the equilibrium potentials of the systems $\mathrm{Sn} / \mathrm{SnO}, \mathrm{Sn} / \mathrm{SnO}_{2}$ and $\mathrm{Sn} / \mathrm{Sn}(\mathrm{OH}) \mathrm{Cl}$, Hoar ${ }^{(20)}$ reported that, the basic salt $\mathrm{Sn}(\mathrm{OH}) \mathrm{Cl}$ is formed in preference to any other oxide when the $\mathrm{pH}$ is below 2.5. Under these conditions, the passivation film will be constituted partially of basic salt and at a lower potential constituted entirely of oxide. Accordingly, the development of a dense tin oxy chloride film occurred by the reaction ${ }^{(20)}$ :

$$
\mathrm{Sn}^{2+}+\mathrm{Cl}^{-}+2 \mathrm{H}_{2} \mathrm{O}_{(\mathrm{L})} \longrightarrow \mathrm{Sn}(\mathrm{OH}) \mathrm{Cl} \mathrm{H}_{2} \mathrm{O}_{(\mathrm{S})}+\mathrm{H}^{+}
$$

This reaction involved the following steps:

a- Adsorption of $\mathrm{Cl}^{-}$on the oxide/ solution interface in competition with $\mathrm{OH}^{-}$or $\mathrm{H}_{2} \mathrm{O}$ molecules for surface sites on the hydrated oxide surface.

b- Formation of the basic tin- hydroxy chloride salt with tin oxide cations on the hydrated oxide surface ${ }^{(\mathbf{2 0})}$.

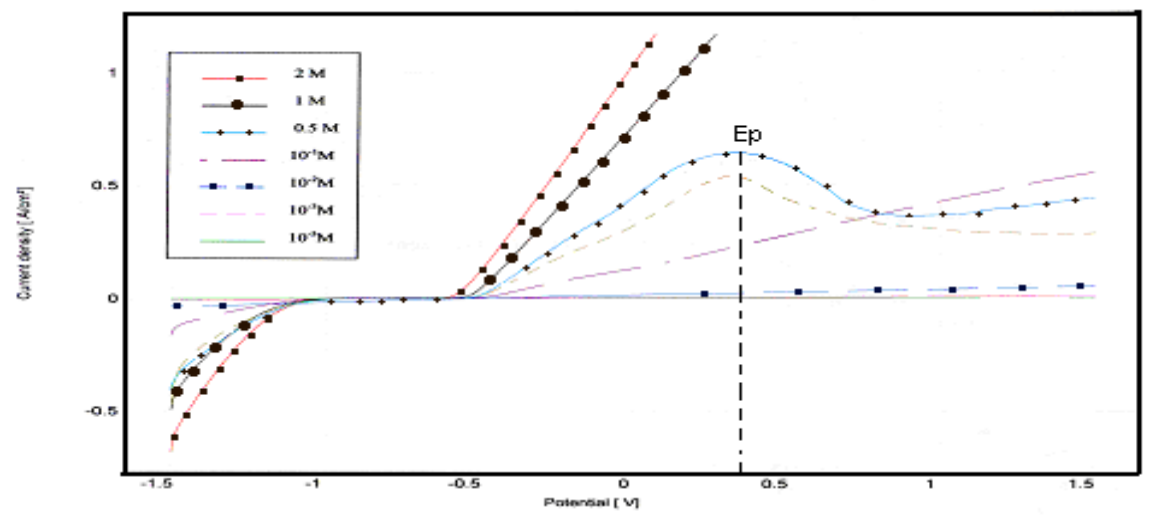

Figure (7): Potentiodynamic anodic and cathodic polarization curves of tin electrode in different concentrations of $\mathrm{HCl}$ acid solutions 


\section{(b)- Behavior of tin electrode in nitric acid}

A cathodic minimum, which increased in depth by increasing the acid concentration, is observed in all concentrations of $\mathrm{HNO}_{3}$ solution (Figure 8). The rate of anodic dissolution is very slow at low acid concentrations and increased considerably with increasing concentration.

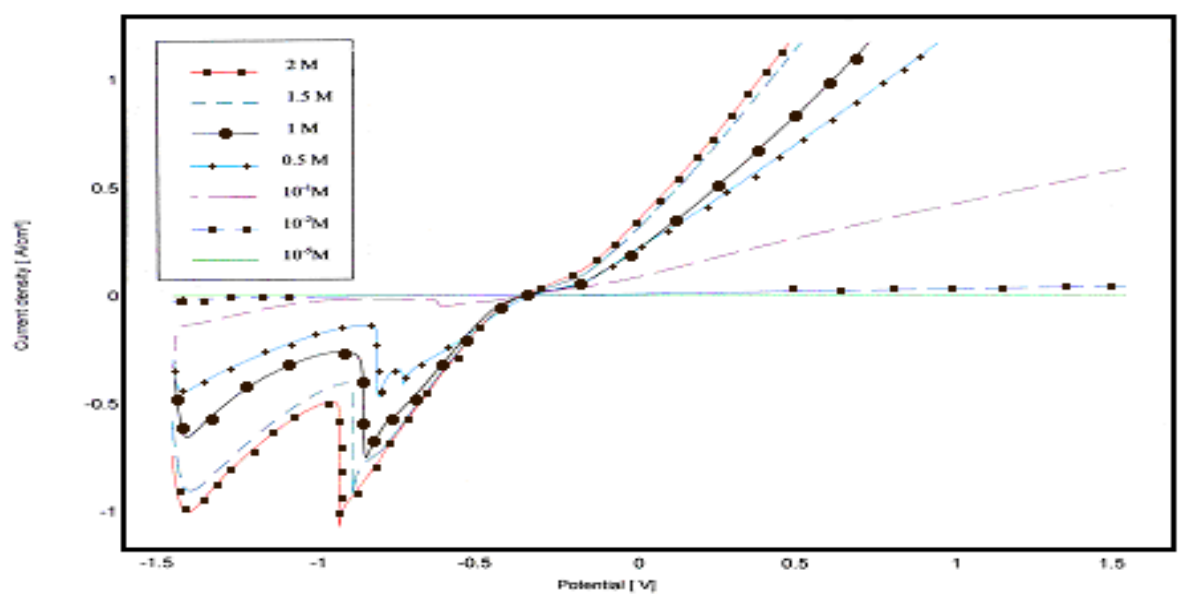

Figure (8): Potentiodynamic anodic and cathodic polarization curves of tin electrode in different concentrations of $\mathrm{HNO}_{3}$ acid solutions

Mechanism for dissolution of tin in nitric acid solutions is assumed to take place according to an autocatalytic mechanism involving the formation of $\mathrm{HNO}_{2}$. The primary process is the displacement of $\mathrm{H}^{+}$from the solution,

$$
\begin{array}{ll}
\mathrm{H}^{+}+\mathrm{e}^{-} \longrightarrow & \mathrm{H} \\
\mathrm{H}+\mathrm{HNO}_{3} \longrightarrow & \mathrm{H}_{2} \mathrm{O}+\mathrm{NO}_{2}
\end{array}
$$

The nitrogen dioxide produced would be adsorbed on the metal surface where it would be reduced according to,

$$
\mathrm{NO}_{2}+\mathrm{e}^{-} \longrightarrow \mathrm{NO}_{2}^{-}
$$

This reaction would be followed by,

$$
\mathrm{NO}_{2}^{-}+\mathrm{H}^{+} \longrightarrow \mathrm{HNO}_{2}
$$

At high acid concentrations the undissociated $\mathrm{HNO}_{2}$ will react with $\mathrm{HNO}_{3}$.

$$
\mathrm{HNO}_{2}+\mathrm{HNO}_{3} \longrightarrow 2 \mathrm{NO}_{2}+\mathrm{H}_{2} \mathrm{O}
$$


In this mechanism two $\left(\mathrm{NO}_{2}\right)$ molecules are produced while one is consumed. This increase in $\mathrm{NO}_{2}$ concentration was responsible for the increase in the rate of dissolution.

(c)- Behavior of tin electrode in sulphuric acid

The E- I curves of Figure (9) illustrated clearly that the current increased sharply by increasing the potential at high concentrations of acid. In low concentrations, the current increased smoothly by increasing potential to the limiting current corresponding to the passive region. With respect to $\left(\mathrm{H}^{+}\right)$and $\left(\mathrm{SO}_{4}^{--}\right)$ions, it was suggested that $\left(\mathrm{SO}_{4}^{--}\right)$ion participated in the tin dissolution reaction. In sulphuric acid solutions, the $\mathrm{Sn}^{2+}$ ion forms complex anions.

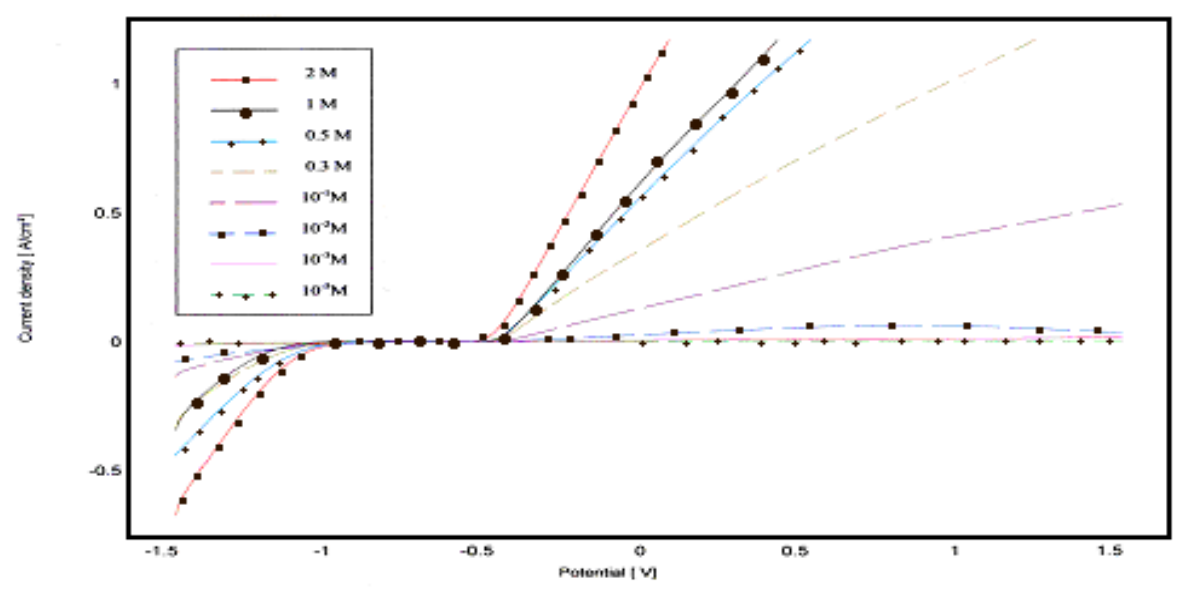

Figure (9): Potentiodynamic anodic and cathodic polarization curves of tin electrode in different concentrations of $\mathrm{H}_{2} \mathrm{SO}_{4}$ acid solutions

There is some dispute about the nature of these anions. Both $\operatorname{Sn}\left[\operatorname{Sn}\left(\mathrm{SO}_{4}\right)_{2}\right]$ and $\mathrm{H}_{2} \mathrm{Sn}_{2}\left(\mathrm{SO}_{4}\right)_{3}$ groups have been proposed. Another authors ${ }^{(21)}$ proposed $\mathrm{Sn}(\mathrm{OH})^{+}$ion and $\left[\mathrm{Sn}(\mathrm{OH}) \mathrm{SO}_{4}\right]^{-}$complexes. There are an equilibrium between $\mathrm{Sn}^{2+}$ and $\left[\mathrm{Sn}(\mathrm{OH})_{4}\right]^{2-}$ in dilute sulphuric acid ${ }^{(22)}$. These results indicated that both $\mathrm{OH}^{-}$and sulphate groups could interfere with the electrode reaction.

The reaction scheme for anodic tin dissolution can be given as ${ }^{(23)}$ :

$$
\mathrm{SnHSO}_{4} \mathrm{OH}^{-}{ }_{\text {ads }}+\mathrm{H}^{+}+\mathrm{e}^{-} \rightleftharpoons \mathrm{Sn}+\mathrm{H}_{2} \mathrm{O}+\mathrm{HSO}_{4}^{-}
$$




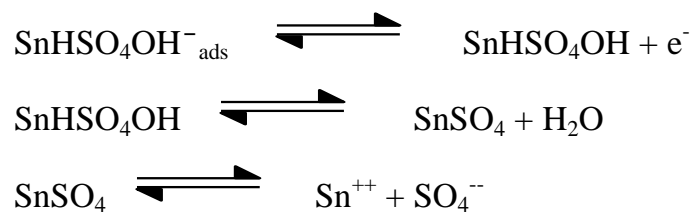

From the above reactions, it can be concluded that the tin dissolution in sulphuric acid occurs through the participation of both $\mathrm{OH}^{-}$and $\mathrm{SO}_{4}^{--}$ions through an intermediate of $\left(\mathrm{SnHSO}_{4} \mathrm{OH}\right)$ species ${ }^{(23)}$.

(d)- Behavior of tin electrode in phosphoric acid

When the potential is raised, dissolution of tin electrode take place and then the current started to oscillate followed by the appearance of anodic peak (Figure 10). The peak potential $\left(\mathrm{E}_{\mathrm{P}}\right)$ did not occur significantly in $10^{-5} \mathrm{M}$ or in $10^{-3}$ and $10^{-2} \mathrm{M}$ solution. Whereas increasing concentration enhanced the height of the peaks and their potential shifted towards negative values. These observations can be explained by the formation of soluble phosphate complex ions such as $\mathrm{Sn}\left(\mathrm{HPO}_{4}\right)_{2}{ }^{2-}$ or $\mathrm{Sn}\left(\mathrm{H}_{2} \mathrm{PO}_{4} \cdot \mathrm{HPO}_{4}\right)^{(24)}$.

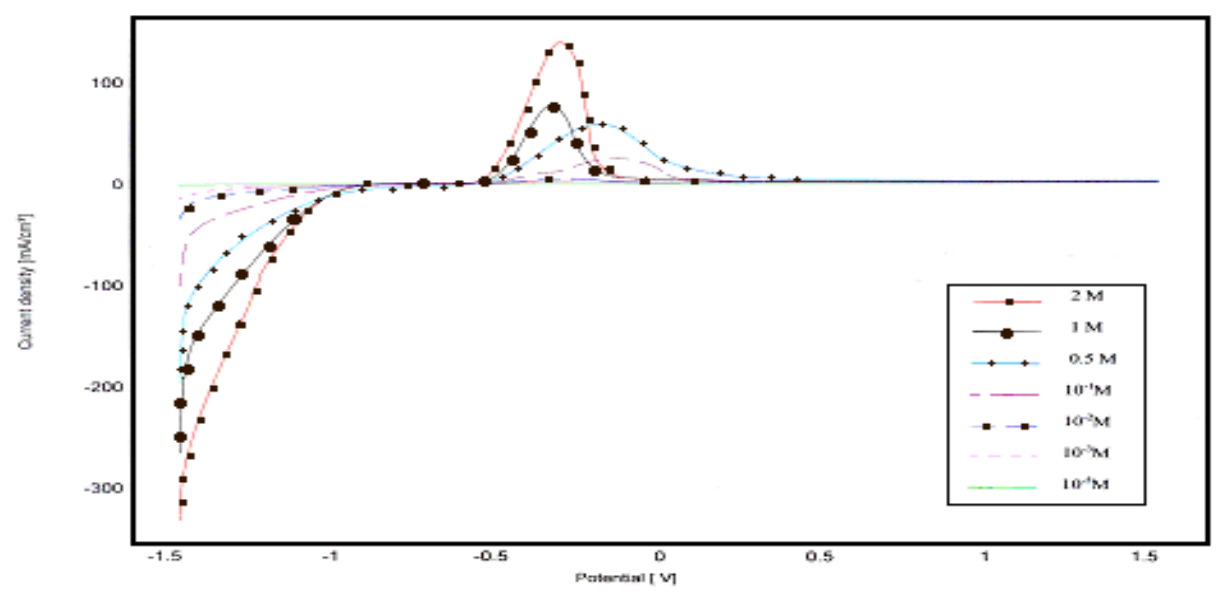

Figure (10): Potentiodynamic anodic and cathodic polarization curves of tin electrode in different concentrations of $\mathrm{H}_{3} \mathrm{PO}_{4}$ acid solutions 
The current oscillations are weak and generally disappear in dilute solutions. This phenomenon is consistent with the formation of oxides of higher valances and oscillatory behavior is observed as a result of transition between the different states of over passivity.

The following reactions are proposed to account for the oxidation behavior of tin electrode in phosphoric solution ${ }^{(25)}$ :
(a) $\mathrm{Sn}+\mathrm{OH}^{-} \longrightarrow \mathrm{SnOH}^{+}+2 \mathrm{e}^{-}$
(b) $\mathrm{Sn}+\mathrm{HPO}_{4}^{--}+\mathrm{H}_{2} \mathrm{PO}_{4}{ }^{-} \longrightarrow$ tin phosphate complexes
(c) $\mathrm{SnOH}^{+}+\mathrm{OH}^{-} \longrightarrow \mathrm{Sn}(\mathrm{OH})_{2}$
(d) $\mathrm{SnOH}^{+}+\mathrm{HPO}_{4}^{--}+\mathrm{H}_{2} \mathrm{PO}_{4}^{-} \longrightarrow$ basic tin phosphates
(e) $\mathrm{Sn}+2 \mathrm{OH}^{-} \quad \longrightarrow \quad \mathrm{Sn}(\mathrm{OH})_{2}+2 \mathrm{e}^{-}$
(f) $\mathrm{Sn}(\mathrm{OH})_{2}+2 \mathrm{OH}^{-} \longrightarrow \mathrm{Sn}(\mathrm{OH})_{4}+2 \mathrm{e}^{-}$
(g) $\mathrm{Sn}+4 \mathrm{OH}^{-} \longrightarrow \mathrm{Sn}(\mathrm{OH})_{4}+4 \mathrm{e}^{-}$

Reactions (a) and (b) accounted for the formation of soluble products. The formation of the passive film seemed to occur by reactions (c), (d) and (f). As an alternative to (c), reaction (e) was proposed which accounted for the direct formation of stannous hydroxide from tin electrode. Analysis of the anodic layer suggested that $\mathrm{Sn}(\mathrm{OH})_{2}$ or $(\mathrm{SnO})$ and $\mathrm{Sn}(\mathrm{OH})_{4}$ or $\mathrm{SnO}_{2}$ is present on the electrode surface at the beginning of the polarization.

Table (4) illustrated the electrochemical parameters calculated from Tafel relations in different acid solutions. Decreasing concentrations of the studied acids led to decrease of the corrosion rate (except for $\mathrm{HCl}$ ). Also the corrosion potential shifted to more positive values but at lower concentrations of nitric acid, decreasing concentration would shift $\mathrm{E}_{\text {corr }}$ towards more negative values. It was also noted that the values of corrosion rate of nitric acid were very high compared with other studied acids indicating the high corrosivety of nitric acid under potentiodynamic conditions. 
Table (4): The electrochemical parameter of tin electrode in different acid solutions and concentrations

\begin{tabular}{|c|c|c|c|c|c|c|}
\hline \multirow{2}{*}{ Solution } & \multirow{2}{*}{$\begin{array}{c}\text { Conc. } \\
\mathrm{M}\end{array}$} & \multirow{2}{*}{$\begin{array}{c}\mathrm{E}_{\text {corr. }} \\
\mathrm{mV}(\mathrm{SCE})\end{array}$} & \multirow{2}{*}{$\begin{array}{c}\mathrm{i}_{\text {corr. }} \\
\mathrm{mA} / \mathrm{cm}^{2}\end{array}$} & \multicolumn{2}{|c|}{$\begin{array}{l}\text { Tafel Slopes } \\
(\mathrm{mV} / \text { decade })\end{array}$} & \multirow{2}{*}{$\begin{array}{c}\text { Corrosion rate } \\
\mathrm{mm} / \mathrm{y}\end{array}$} \\
\hline & & & & $\mathrm{B}_{\mathrm{c}}$ & $\mathrm{B}_{\mathrm{a}}$ & \\
\hline \multirow{8}{*}{$\vec{U}$} & 2.0 & -911.7 & 0.422 & 126 & -101.9 & 5.017 \\
\hline & 1.0 & -907.9 & 0.524 & 208 & -136.0 & 8.590 \\
\hline & 0.5 & -881.9 & 0.554 & 289 & -127.4 & 6.577 \\
\hline & 0.3 & -876.6 & 0.463 & 165 & -129.1 & 5.494 \\
\hline & $1 \times 10^{-1}$ & -623.5 & 0.624 & 467 & -146.4 & 7.412 \\
\hline & $1 \times 10^{-2}$ & -477.5 & 1.460 & 318 & -327.4 & 17.41 \\
\hline & $1 \times 10^{-3}$ & -437.7 & 1.590 & 350 & -338.8 & 18.962 \\
\hline & $1 \times 10^{-5}$ & -436.0 & 1.510 & 341 & -319.0 & 18.992 \\
\hline \multirow{7}{*}{$\begin{array}{l}\text { O̊ } \\
\text { Ż }\end{array}$} & 2.0 & -453.2 & 53.27 & 324 & -329.2 & 632.1 \\
\hline & 1.5 & -401.2 & 29.76 & 311 & -209.0 & 353.1 \\
\hline & 1.0 & -390.0 & 23.61 & 292 & -198.7 & 280.2 \\
\hline & 0.5 & -369.6 & 17.07 & 284 & -181.5 & 202.5 \\
\hline & $1 \times 10^{-1}$ & -391.2 & 16.74 & 407 & -531.2 & 198.6 \\
\hline & $1 \times 10^{-2}$ & -484.8 & 0.913 & 470 & -578.7 & 10.83 \\
\hline & $1 \times 10^{-5}$ & -531.5 & 0.274 & 358 & -451.7 & 3.257 \\
\hline \multirow{8}{*}{$\begin{array}{l}0^{+} \\
\mathscr{W}^{\prime} \\
I^{\prime}\end{array}$} & 2.0 & -979.0 & 0.700 & 153 & -104 & 7.98 \\
\hline & 1.0 & -970.6 & 0.660 & 426 & -123 & 7.920 \\
\hline & 0.5 & -843.4 & 0.300 & 131 & -114 & 3.563 \\
\hline & 0.3 & -824.0 & 0.300 & 274 & -125 & 3.400 \\
\hline & $1 \times 10^{-1}$ & -563.4 & 0.330 & 63.0 & -685 & 3.922 \\
\hline & $1 \times 10^{-2}$ & -517.0 & 0.310 & 125 & -420 & 3.680 \\
\hline & $1 \times 10^{-3}$ & -486.9 & 0.274 & 292 & -113 & 3.631 \\
\hline & $1 \times 10^{-5}$ & -474.0 & 0.195 & 400 & -328 & 2.319 \\
\hline \multirow{7}{*}{ 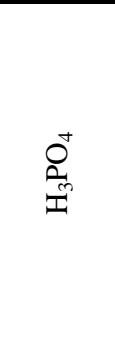 } & 2.0 & -889.7 & 0.799 & 206.4 & -138.8 & 9.488 \\
\hline & 1.0 & -876.7 & 0.753 & 217.1 & -144.0 & 8.943 \\
\hline & 0.5 & -587.3 & 0.796 & 96.20 & -423.0 & 9.450 \\
\hline & $1 \times 10^{-1}$ & -585.2 & 0.357 & 114.0 & -746.0 & 4.230 \\
\hline & $1 \times 10^{-2}$ & -587.4 & 0.349 & 171.0 & -883.0 & 4.140 \\
\hline & $1 \times 10^{-3}$ & -567.0 & 0.340 & 265.6 & -326.0 & 4.059 \\
\hline & $1 \times 10^{-5}$ & -536.0 & 0.170 & 345.5 & -330.0 & 0.208 \\
\hline
\end{tabular}




\section{Conclusion}

From the aforementioned results of open circuit potential measurements it could be concluded that depending on steady state potential values the corrosivety of acids used for mechanically polished and non- polished electrodes was assumed to increase in the following order: $\mathrm{HNO}_{3}<\mathrm{H}_{2} \mathrm{SO}_{4}<\mathrm{HCl}<\mathrm{H}_{3} \mathrm{PO}_{4}$.

Potentiodynamic techniques revealed that, tin electrode might be safely used in low concentrations of $\mathrm{H}_{2} \mathrm{SO}_{4}$ and $\mathrm{H}_{3} \mathrm{PO}_{4}$ acids $\left(10^{-1}\right.$ to $\left.10^{-5} \mathrm{M}\right)$ where the corrosion rate was low. At high concentrations it could be protected. $\mathrm{In} \mathrm{HCl}$ acid the metal reflex its behavior, consequently it may be used safely at high concentrations ( 0.3 to 2M) only. $\mathrm{HNO}_{3}$ registered very high corrosion rate at all concentrations due to increase in $\mathrm{NO}_{2}$ concentration.

\section{References}

1. ISMAEL DIEZ- PEREZ, FAUSTO SANZ AND PAU GOROSTIZA; Current Opinion in Solid state and Materials Science, 10 (3-4) pp. 144 (2007).

2. HIKOZÔ ENDÔ AND GORÔ YOKOYAMA; Science Repts. Research Insts., Ser. A 2 pp. 449 (1950).

3. V. A. KHITROV AND V. I. SHATALOVA; (Teachers Inst. Voronezh), Zhur. Priklad Khim., 34 pp. 2106 (1961).

4. HIKOZÔ ENDÔ AND GORÔ YOKOYAMA; Science Repts. Research Insts., Ser. A 2 pp. 456 (1950).

5. D. W. JONES; J. Soc. Chem. Ind., 47 pp. 161 (1928).

6. A. RAGHEB AND L. A. KAMEL; Corrosion, 18 pp. 153 (1962).

7. AL-SUHYBANI AND A. ABDULAZIZ; Surf. Coat. Technol., 34( 4) pp. 463 (1988).

8. HIKOZÔ ENDÔ AND GORÔ Yokoyama; Science Repts. Research Insts., Ser. A 2 pp. 637 (1950).

9. F.OTTWATER; Mater.Protect.,4 (11) pp. 65 (1965).

10. K. GAMAL GOMMA; Energetics Chemistry Earth Environmental and Biomedical Problems, 50(1- 3) pp. 39 (1995). 
11. C. M. ALMEIDA, T. RABOCZKAY AND B. F. GIANNETTI; Journal of Applied Electrochemistry, 29 (1) pp.123 (1999).

12. S. S. ABD EL-REHIM, S. M. SAYYAH AND M. M. EL- DEEB; Materials Chemistry and Physics, 80 (3) pp.696 (2003).

13. S. S. ABD EL-REHIM, H. H. HASSAN AND F. N. MOHAMED; Corrosion Science, 46 (5) pp. 1071 (2004).

14. E.H. AIT ADDI, L. BAZZI, M. ELHILALI, ZINE EL-ALAMI, R. SALGHI, AND EL-ISSAMI SOUAD; Canadian Journal of Chemistry, 81( 4) pp. 297 (2003).

15. E.H. AIT ADDI, L. BAZZI, M. ELHILALI, R. SALGHI, B. HAMMOUTI AND M. MIHIT.; Applied Surface Science, 253(2) pp. 555 (2006).

16. U. R. EVANS; "An Introduction to Metallic corrosion", third Edition, Edward Arnold, London (1981).

17. J. M. ABD EL-KADER AND A. M. SHAMS EL-DIN; BR. CORROSION J., 14 (1) pp. 40 (1979).

18. R. STEINHERZ; Ueber Passives Zinn, Z. Elektroch, 30 pp. 279 (1924).

19. BOURBAIX pp. 479 (1974).

20. T. P. HOAR; Trans. Faraday Soc., 33 pp. 1152 (1937).

21. G. GORDON AND C. H. BRUBAKER; J. Am. Chem. Soc., 82 pp. 4448 (1960).

22. T. ITO AND M. ABE; KOGYO Kagaku Zasshi, 63 pp. 1699 (1960).

23. M. Natesan and S. Venkatakrishna Iyer; Key - Engineering-Materials, (20-28) pp. 531 (1988).

24. S. A. AWAD AND A. KASSAB; J. Electroanal. Chem., 20 pp. 203 (1969).

25. H. DO DUC AND P. TISSOR; Corrosion Science, 19 pp. 179 (1979). 